\title{
„Literatura jako ekspresja ducha”. Tomasz Burek
}

DOI: http://dx.doi.org/10.12775/LC.2018.036

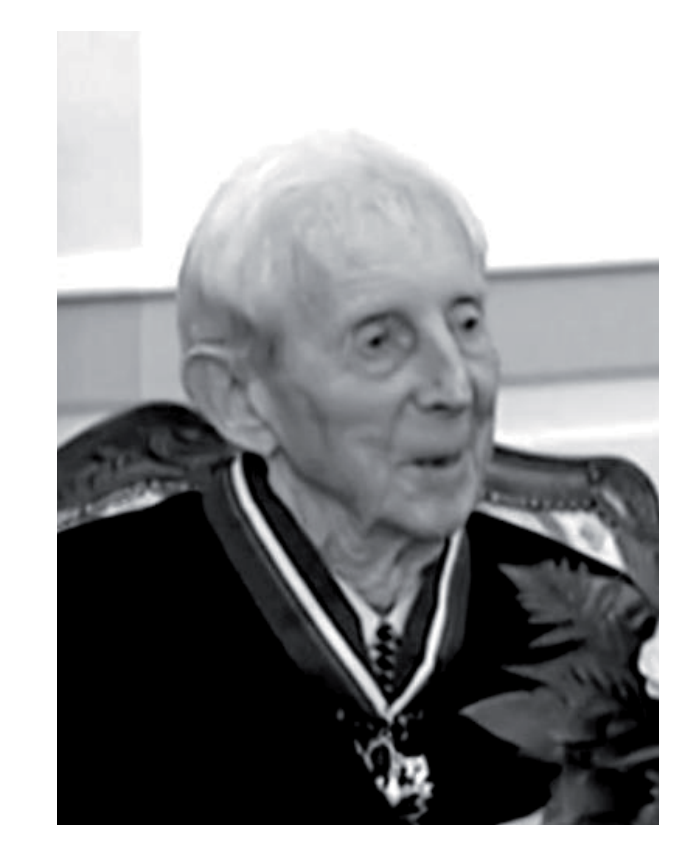

Tomasz Burek odznaczony Medalem Gloria Artis (fot. na podstawie materiału telewizyjnego)

$$
1 .
$$

11 oją całą podstawą - pisał Novalis o sobie - jest głębokie przywiązanie do życia, wiara i ufność we wszystko, co jest we mnie i wokół mnie” (Novalis 1983: 50) i dodawał: „...człowiek ostaje się dzięki prawdzie. Jeśli wyrzeka się jej, to wyrzeka się siebie” (Novalis

\footnotetext{
Profesor nadzwyczajny, historyk literatury w Instytucie Literatury Polskiej Uniwersytetu Mikołaja Kopernika wToruniu.E-mail: alef2@wp.pl.
} 
1984: 87). Słowa jednego z przedstawicieli niemieckiego romantyzmu, wielbiciela „kultury intelektu" stanowią ważne tło dla refleksji poświęconej współczesnej literaturze i sztuce. Jej źródła ukształtował wiek dziewiętnasty, w szczególności okres schyłkowy, obfitujący w odkrycia i wynalazki. Odzyskaniu niepodległości w roku 1918, w wyniku Wielkiej Wojny, towarzyszyły narodziny nowych dyskursów o sztuce i literaturze eksperymentalnej, wolnej, ekspresywnej. Nowoczesność i tradycja, sztuka i literatura zawarły przymierze, którego skutki trudno dziś przecenić. Krytyka literacka stała się jednym z ważnych zadań, jakie stawiała przed sobą współczesna humanistyka. W obliczu przemian społecznych i politycznych była wyrazem „kultury intelektu”, niekiedy także - niezłomności, wiary w twórczą moc słowa.

Jednym z najbardziej znanych i cenionych krytyków literatury, który pozostawił po sobie wiele cennych prac, stanowiących źródło postaw, zapis historii „czasów pogardy”, świadectwo nieustannych wyborów - był Tomasz Burek. Jak czytamy w artykule Czesława Miłosza pt. O poezji polskiej czasów wojny („Tygodnik Powszechny” 1980, nr 50): „w chwili dziejowej, gdy nic nie zależy od człowieka, wszystko zależy od człowieka"1, słowa te wydają się charakteryzować zarówno rozwój zawodowy Tomasza Burka, jak i jego życiowe wybory. Działalność naukowa wpisana w nurt życia społecznego, ujawniła bogactwo idei humanizmu, odsłoniła filozoficzne podstawy głoszonych poglądów, które zawsze dotyczyły człowieka, jego praw i obowiązków wobec świata. W jednej z autorskich książek, opublikowanych w 2001 roku pt. Dzieło niczyje, autor wspomina o tym, że „... nie ma już idei człowieka wiecznego, abstrakcyjnego. Człowiek wieczny został uśmiercony, przepadl, w zamian witamy z radością człowieka konkretnego, poszczególnego, z jego ciałem, z konkretną egzystencją, wypełnioną codziennymi kłopotami, lękami, troskami” (Burek 2001a: 7). „Człowiek konkretny” nigdy nie przysłonił w twórczości Tomasza Burka postaci „człowieka absolutu”, nie był jednak pomijany w refleksjach o literaturze i sztuce minionego stulecia. Przejście, od metafizyki do filozofii konkretu, które dokonało się na oczach powojennego pokolenia, nie mogło pozostać bez komentarza, w licznych pracach poświęconych poezji, m.in. Iwaszkiewicza, Lechonia, czy Herberta, powraca echo rozważań poświęconych pustce, która powstaje z powodu utraty metafizycznej „podstawy istnienia”. W cytowanym eseju pt. Literatura, niepoważne zajęcie sytuacja ta zostaje scharakteryzowana jako nieuchronna, pozbawiająca jednostkę nadziei, jako - melancholijna samotność:

Nasz świat, ten świat z pozoru tak rzeczywisty, namacalny, a pod spodem, u samego dna, pozbawiony oparcia w czymś pozaświatowym, ostatecznym, nieuwarunkowanym, ten właśnie świat umyka nam, przecieka przez palce, rozwiewa się jak dym, desubstancjalizuje, przybierając na koniec postać samounicestwiającej się otchłani (ibid.: 9).

Ten niezwykły stan, w którym jednostka traci poczucie stabilizacji, brakuje jej bowiem metafizycznych „fundamentów” w refleksji o istnieniu, jego sensie, wpływa także na twórczość, przede wszystkim na literaturę i sztukę, jak postrzega jej zadania Tomasz Burek:

Wydaje się zatem, że stopniowy zanik, a wreszcie utrata poczucia rzeczywistości, będąca skutkiem rozmaitych procesów natury intelektualnej, kulturowej i społecznej, to właśnie ten

\footnotetext{
1 Fragment cytowanego zdania został użyty przez Tomasza Burka jako motto w artykule pt. Dialog wolności i konieczności albo historyczne wtajemniczenie (Burek 1981).
} 
tajemniczy czynnik, który w decydujący sposób wplynął na oblicze artystycznej twórczości w XX wieku. Sztukę XX wieku, malarstwo, rzeźbę, literaturę, ukształtowały - jak to dzisiaj widzę - konsekwencje przerwania związku myślowego z metafizyką, eksmisja absolutu z kultury - być może tymczasowa, $\mathrm{w}$ każdym razie wyparcie absolutu z centrum na dalekie prowincje i peryferie twórczego myślenia, praktyczne zamazanie tego, co transcendentne, boskie, święte, próba obycia się bez sankcji wieczności w myśleniu i tworzeniu” (ibid.: 10).

Refleksja o peryferiach twórczego myślenia towarzyszyła krytykowi w niemalże wszystkich badawczych peregrynacjach. To właśnie w twórczej działalności człowieka ukrywa się „prawda o absolucie”, tęsknota za metafizyką - pojmowaną poniekąd w modernistyczny sposób, a zatem w ścisłym związku ze sztuką, o których wspominał autor Dzieła niczyjego. Jego refleksje o sztuce i literaturze nosiły piętno indywidualizmu, twórczego, niekiedy nawet intymnego „odbioru” dzieła. Czy strategia intymna sprzyjała pracy krytyka literackiego? Intymność nie była nigdy wyrażana wprost. Refleksja o postaciach i dziełach pozwalała mówić o sobie samym, stwarzała szansę zrozumienia świata, w którym żyje człowiek, współtworzy go i zarazem niszczy². Myśl humanistyczna ogarnęła wszystkie ważne dziedziny życia, sztuka i literatura - przesiąknięte nią - doskonale odzwierciedlały kierunki rozwoju współczesnego świata. A zatem, u podstaw dzieła Tomasza Burka, spuścizny, którą pozostawił po sobie, można dostrzec metafizyczne pragnienie, nieustanną, podsycaną doświadczeniem tracącej podstawy w codzienności - pogoń za absolutem. W przepięknym eseju o Jarosławie Iwaszkiewiczu krytyk nie tylko zwraca uwagę na „fundamentalne prawdy” zawarte w twórczości poety, „jednego ze Skamandra” - osobnego jednak, zagubionego we współczesności, ważna wydaje się także biografia niepokornego twórcy, który nie tylko tworzy „Księgę Zmysłów” (Burek 2001b: 104)³, dopełnia ją „Księgą Ducha” (ibid.). Dualizm istnienia, niezwykły, niekiedy trudno wyczuwalny moment przejścia tego, co materialne w sfery duchowe w twórczości poety, wydaje się najbardziej fascynować Burka. O istocie twórczości, jak zdaje się ją rozumieć krytyk, świadczy gest odrzucenia ogólnie przyjętej zgody na zastany świat, walka tego, co immanentne w życiu z tym, co transcendentne (ibid.: 107), stanowiące próbę uporządkowania chaotycznej codzienności. Poezja porządkuje świat, wprowadza w sferę sensu. Iwaszkiewicz - jak żaden inny poeta sięgał po metafizykę codzienności, uwydatniał lęki i niepokoje egzystencji, by zrozumieć siebie, odnaleźć „miejsce na ziemi”. Refleksja metafizyczna stanowiła rewers jego twórczości, w której pobrzmiewał introspekcyjny ton (ibid.: 109), była ściśle sprzęgnięta z intelektualnym realizmem. Filozofia codzienności nie mogła obyć się bez sakralnych odniesień. Sztuka, literatura (w szczególności poezja) odsłaniały „ukryty wymiar” istnienia, nie brakowało w nim sakralnej przestrzeni, w której - jak w niektórych wierszach Leśmiana - spotkanie z Bogiem dokonuje się w „zieloności” natury, w jej żywiołowym istnieniu.

Iwaszkiewicz, zdaniem Burka - kieruje swoje myśli w stronę mistycyzmu. Obecne w jego twórczości symbole - wody (źródła), ognia, ziemi (natury) współtworzą metafizyczny obraz świata, jego sakralno - realną postać (ibid.: 118). Krytyk przywołuje w eseju pt. Co jest jeszcze do odkrycia w Iwaszkiewiczu? słowa Ludwika Wittgensteina, dla którego pojęcie mistycyzmu łączy się z doświadczeniem pełni egzystencji, z jej przeżyciem: „Mistyczne - to

2 W eseju pt. Literatura, niepoważne zajęcie Tomasz Burek (2001: 6) pisze: „Krępuję się mówić »ja«, »ja« więc będę »ja«, ale w przecięciu z czymś ogólniejszym".

3 Por. T. Burek, Co jeszcze do odkrycia w Iwaszkiewiczu? 
nie - jaki jest świat, lecz fakt, że świat jest” (ibid.). Jak można przypuszczać, uwaga ta jest bliska krytykowi, może być uznana także za motto jego prac poświęconych poezji.

\section{2.}

W licznych esejach o literaturze (m.in. twórczości Amiela, Jana Lechonia Roberta Musila, zwłaszcza powieści pt. Człowiek bez właściwości, Zbigniewa Herberta, Witolda Gombrowicza, Gustawa Herlinga - Grudzińskiego) Tomasz Burek szukał zwykle przyczyn ludzkich działań, interesowały go źródła i podstawy istnienia. Pragnienie „zaglądania pod podszewkę bytu" miało bez wątpienia dziennikarki rodowód. Eseje o literaturze przeradzały się w opowieści o ludziach, ich pragnieniach, podróżach, o wielkich klęskach i radościach. W ten sposób powstawała niezwykła narracja o współczesności, przetkana cennymi uwagami o związkach sztuki, literatury i życia (por. eseje o Jarosławie i Annie Iwaszkiewiczach, Burek 2001b: 96-133) $)^{4}$ Antoni Libera w laudacji wygłoszonej podczas wręczenia Złotego Medalu „Gloria Artis” w 2016 r., określił twórczość Tomasza Burka mianem „literatury o literaturze” (Libera 2016: 54), nawiązał w ten sposób do źródłowego znaczenia pojęcia „krytyki literackiej”. Refleksja o „naturze rzeczy”, łącząca różne aspekty oglądu: filozoficzne, religijne, społeczno-kulturowe, polityczne, pozwala zrozumieć świat we wszelkich odsłonach, czyni go przyjaznym. Szczególne miejsce w refleksji odgrywa literatura, która - jak żadna inna ze sztuk, łączy wymienione aspekty: filozoficzne, religijne, społeczno - kulturowe i polityczne w jeden ciąg, tworzy odrębny język obrazów i znaczeń, wciąż jednak uczy stawiania pytań i poszukiwania odpowiedzi. Tym, co wydaje się najistotniejsze w trwającym nieustannie dyskursie współczesności, wydaje się jednak pytanie o duszę, które pobrzmiewa w licznych esejach Burka. Autor przywołuje twórczość romantyków i neoromantyków (sięga w nich po dzieła Mickiewicza, Mochnackiego, Amiela, Rimbauda i Brzozowskiego), formułuje pytania o duchowość Europy. W odpowiedzi - jak w eseju pt. Inny mur z tomu Dziennik kwarantanny relacjonuje opis spotkania z Krzysztofem Zanussim, który próbuje uzmysłowić publiczności, że: „dobra kultura to kultura szlachetna i elitarna, zatem zmuszająca odbiorcę do wysiłku. To ona jest ku zbudowaniu (i zbawieniu) człowieka, w ostatecznym bowiem rachunku, nawet gdy nie jest wprost motywowana religijnie, pozwala obcować z innym wymiarem rzeczy i tajemnicami losu, czyniąc człowieka lepszym” (Burek 2001b: 66). Współczesny wymiar kultury staje się wiernym odzwierciedleniem ludzkich tęsknot za nieśmiertelnością, potęgą, władzą poznania, czy jednak tęsknoty te mają szansę realizacji? Dla Tomasza Burka ważniejsze wydaje się pytanie o podstawę etyczną, o racje dostateczne, a zatem, czy marzenia i tęsknoty mogą być zrealizowane? Czy człowiek poszukujący nieśmiertelności, potęgi i władzy nie przekracza wyznaczonych granic? Pytania o wartości stanowią fundamenty refleksji o człowieku współczesnym, jakie zostały przedstawione $\mathrm{w}$ tomie pt. Dziennik kwarantanny. Tytułowa kwarantanna jest czasem wyjątkowym, w którym dokonuje się „oczyszczenie myśli”, przegląd postaw - zachowań, rodzi bowiem refleksje: „W ogóle jestem kimś innym” (Lodołamcz „Stanisław Czycz”; Burek 2001b: 67). Refleksja ta dojrzewa w cieniu poezji: „...jak uśmiech, którego od grymasu melancholii odróżnić nie

4 T. Burek, Co jest jeszcze do odkrycia w Iwaszkiewiczu? 
sposób” (Epilog wenecki?; ibid.: 98). W poezji bowiem: „...jak w życiu samym - każda odpowiedź pociąga za sobą nowe pytanie, każdy koniec jest jednocześnie otwarciem, każda granica - bezkresem" (ibid.). Poezja, literatura splata się bowiem z życiem, odzwierciedla jego „przełomy”, ujawnia „napięcia”, tworzy „wyobrażenia”, które pozwalają na spojrzenie z boku, lub nawet „z ukosa”. W krytycznoliterackim dyskursie Tomasza Burka nie brakuje tego typu spojrzeń, zabarwionych nutą ironii. Nie mają one jednak kąśliwego charakteru. Ironia - jak ją pojmowali romantycy, m.in. Søren Kierkegaard - jest wyłącznie „figurą myśli”, jej metafizycznym fundamentem, pozwala na dystans, który wydaje się niezbędny w refleksji o rzeczywistości i jej wytworach. Dystans ten zaznacza się m.in. w wypowiedziach o twórczości poetów, np. Jarosława Marka Rymkiewicza, który zdaniem krytyka, ujawnia „skryty w pseudonimach i przebierankach wstyd pokolenia” (Pan Mareczek jest w złym humorze; ibid.: 159). Tomasz Burek jako krytyk jest „świadkiem historii”, narodowe dzieje, jak pisze, są dla wielu (dla niego także) nadal „rzeczą świętą” (Mówimy po polsku; ibid.: 158). Historia nieustannie powraca w jego esejach o sztuce i literaturze, w których wspomnienia, odniesienia do przeszłości przeplatają się z uwagami o współczesności: „W roku 1918 odzyskaliśmy niepodległy byt państwowy na dwadzieścia dramatycznie krótkich lat. Najechani i okupowani przez zbójeckie ekspansjonizmy, poniżeni, zagrożeni wyniszczeniem, przymuszani do nieprawdziwego życia w urządzonym na sowiecką modłę PRL-u, zdołaliśmy po raz drugi w tym stuleciu wybić się na niepodległość” (ibid.). Przeszłość, zdobycze Wielkiej Wojny zostają więc skonfrontowane $\mathrm{z}$ teraźniejszością, najbliższymi wydarzeniami z roku 1989. Refleksja ta znajduje odniesienie w esejach poświęconych twórczości artystów „skazanych na zapomnienie”, m.in. takich jak np. Andrzej Czycz, czy „poetów historii”, jak Herbert. Poezja - jak podkreślał krytyk - „... stawia na nowo czoło temu wszystkiemu. Zanurzona w substancjach niewysłowionych cierpień, obarczona świadomością »chaosu pożądania udręki $<[. .$.$] przypomni sobie \mathrm{w}$ chwili szczęśliwej, że jest darem niebios, paradoksem" (Węzet ostateczny; ibid.: 102). Historyczne i głęboko etyczne uwarunkowanie sądów krytycznoliterackich znajduje swoje uzasadnienie nie tylko w koncepcji literatury, jaką głosił Burek - zespolonej z myślą etyczną, tworzącą i propagującą humanistyczne wartości, czy koncepcją kultury, w której zanurzony jest człowiek - jej twórca i niszczyciel. Ważne wydaje się także dziedzictwo rodzinnego domu, do którego krytyk wciąż odwoływał się (figura domu jest obecna w wielu jego esejach, por. np. eseje o Iwaszkiewiczu, Herbercie ${ }^{5}$ ).

\section{3.}

Tomasz Burek urodził się w 1938 roku w Warszawie, jednak już w następnym roku, w pierwszych wojennych miesiącach, wraz z Matką - Zofią z Młodożeńców i ojcem Wincentym, działaczem ruchu ludowego, redaktorem i pisarzem, przeniósł się do Sandomierza. Miasto to na zawsze wpisało się w jego biografię, było „małą ojczyzną”. Jego niezwykły obraz powraca w licznych wspomnieniach, m.in. poświęconych Przybosiowi. Przeszłość pełni w nich funkcję zwierciadła, minione zdarzenia, w których krytyk uczestniczył, współtworzył je

\footnotetext{
5 Por. Burek 2001b.
} 
(„strategia świadka - uczestnika”), stanowią odniesienie dla współczesności, pozwalają zrozumieć nowoczesność. Burek nie ocenia jedynie postaw, choć są dla niego interesujące, dostrzega bogactwo myśli, rejestruje „chwilowe epifanie”. Zdarzenie z pogrzebu Przybosia, w którym uczestniczył, stanowi doskonały komentarz do twórczości autora Oburącz, odsłaniający „utajone znaczenia”:

Spełniło się coś, co było obecne w jego poezji. Było w niej takie napięcie ku czemuś, co nie wiązało się dla niego z religią, ale z czymś innym. Jak by to nazwać? Była to religia ateisty, który odrzucał wszystkie prawdy wiary, a jednak wierzył w możliwość „rzutu człowieka w nadprzyrodzone”. Niektórzy nazywają to mistyką, bo była to wiara w wyjście człowieka poza przyrodzone granice. Ten paradoks był widoczny: pogrzeb ateisty, bez obrzędów kościelnych - i coś jakby ponadludzka ingerencja, mocowanie się nad nim, nad jego trumną dwóch porządków (Dakowicz 2016: 25).

Odsłonięty w czasie pogrzebu „prześwit w błękicie” był dla jednych widocznym znakiem transcendencji, dla innych - jedynie przejawem nieobliczalnej natury. Komentarz do zdarzenia wskazuje na kierunek poszukiwań, jaki obrał w życiowej drodze Tomasz Burek, który starał się poznawać rzeczywistość nie tylko w wymiarze rzeczywistym („horyzontalnym”), ważne było także przenikanie w głąb, poszukiwanie prawdy, jej obiektywnego i duchowego wymiaru.

Po ukończeniu I Liceum Ogólnokształcącego (Collegium Gostomianum) w 1955 roku przyszły krytyk literacki rozpoczął studia na Wydziale Dziennikarskim Uniwersytetu Warszawskiego. Jego zamiłowanie do sportu (zwłaszcza koszykówki) spowodowało, że marzył o zawodzie dziennikarza sportowego, szybko jednak sport ustąpił miejsca literaturze. Nie była to jednak „zdrada zainteresowań”, sport - jak czytamy w tomie pt. Żadnych marzeń był dla niego „dyscypliną humanistyczną” (Dakowicz 2006: 32).Tomasz Burek poświęcił się pracy krytyka literackiego, wyznaczając „nowe kierunki rozwoju” badań krytycznoliterackich. O wczesnym okresie swojej działalności pisał:

Krytyka literacka jawi się w takiej perspektywie jako sztuka dla sztuki, którą uprawia się nie wierząc, że z tego będzie jakikolwiek pożytek. Dlatego, kiedy czasem wracam do jakiejś części swego dorobku, bardzo mnie przeraża pouczanie, że ja wiem, jak powinno być. To jest wpływ Brzozowskiego: historię opanować, historię uchwycić. Wizja historii i proces historyczny to dwie różne rzeczywistości (ibid.: 45).

Historia, zwłaszcza najbliższa, kształtowała postawy, była wciąż obecna w twórczości krytyka, który wspominał w Dalej aktualne o trudnych doświadczeniach stalinizmu, siebie i kolegów nazywał „oślepionymi kretami”, wspominał także postać ojca, Wincentego, który sympatyzował z ruchem Stronnictwa Ludowego, nie przyjął jednak zaproszenia Jerzego Putramenta w 1946 roku i nie podjął z nim współpracy w Lublinie.

6 Kategorie Edwarda Balcerzana.

7 Promienie słońca oświetliły głębię grobowej pieczary w czasie pogrzebu.

8 Por. także tom Żadnych marzeń. 


\section{4.}

Tomasz Burek był autorem kilku książek Zamiast powieści (1971), Dalej aktualne (1973), Jaka historia literatury jest nam potrzebna? (1979 - II obieg wydawniczy), Żadnych marzeń (1987, (Londyn; 1989 - II obieg wydawniczy), Dzieło niczyje (2001), Dziennik kwarantanny (2001), Niewybaczalne sentymenty (2011), był także m.in. współautorem naukowych opracowań: Literatura polska 1918-1975 oraz Obraz literatury polskiej XIX i XX wieku. Artykuły krytyczne publikował na łamach licznych czasopism m.in. „Gazeta Polska”, „Życie Literackie”, „Kultura Niezależna” i „Puls”. Otrzymał wiele nagród za swoją działalność, wśród nich warto wymienić: Nagrodę im. Stanisława Piętaka z 1972 roku, Nagrodę Fundacji im Kościelskich w Genewie z 1973 roku, nagrodę krakowskiego „Życia Literackiego” z 1974 roku. W 2007 roku został odznaczony Krzyżem Komandorskim Orderu Odrodzenia Polski. O swojej pracy mówił: „Ale jak się patrzy później, kto to jest Tomasz Burek, to widzi się całkiem spokojnego robotnika pióra, który jednak co jakiś czas układał jakąś książkę, zajmował się sprawami zrozumiałymi, interweniował w rzeczywistość, to znaczy nie był wariatem. Tak można powiedzieć” (Dakowicz 2016: 46). Włodzimierz Bolecki (2016) określił jego działalność jako „strategię buntu”, Adrian Gleń zaś zwrócił uwagę na jej humanistyczny wymiar, nieustanny wysiłek „docierania własnym słowem w stronę Absolutu” (Gleń 2016: 7). Działalność krytycznoliteracka uprawomocniła obecność literatury, poezji w życiu codziennym, nadała jej rangę wspólnotową (por. np. eseje o Herbercie). Tomasz Burek potrafił docenić zalety sztuki słowa w perspektywie historycznych, społecznych (kulturowych) przemian, dostrzegał w niej głos pokolenia, które pielęgnując tradycje wolnościowe, po doświadczeniach Wielkiej Wojny, potrafi docenić współczesność, należycie wykorzystać wszelkie „znaki czasu” (Burek 2001a: 140) ${ }^{9}$. Podczas wręczenia Złotego Medalu „Gloria Artis” w 2016 roku Antoni Libera w wygłoszonej laudacji zwrócił uwagę na to, że „literatura jest nie tylko sztuką, lecz także jedną z form ekspresji ducha człowieka, który poszukuje odpowiedzi na zasadnicze pytania dotyczące jego egzystencji: o sens istnienia na Ziemi, o przeznaczenie, o możliwość i szansę zbawienia” (Libera 2016: 88) - twórczość autora Zamiast powieści doskonale odzwierciedla te zależności, ujawnia sens pracy historyka literatury i krytyka, który nie tylko dostrzega nowe literackie światy, ceni je i dokumentuje.

Współpraca z Instytutem Badań Literackich PAN, którą krytyk podjął w 1970 roku (w 1980 roku przedstawil rozprawę doktorską pt. Krytyka literacka $w$ dwudziestoleciu międzywojennym) zakończyła się w roku 1985. Tomasz Burek został wówczas relegowany za swoją postawę polityczną, m.in. podpisał tzw. Memoriał 101, który stanowił protest środowisk naukowych przeciwko planowanemu zapisowi w Konstytucji PRL-u, mówiącemu o przewodniej roli PZPR i sojuszu z ZSRR. Był to czas najważniejszy - „kształtowania świadomości” (Dakowicz 2016: 25). Przymusowa „banicja” trwała do roku 1989, krytyk twórczo wypełnił ten trudny okres, był m.in. wykładowcą Uniwersytetu Latającego i Towarzystwa Kursów Naukowych, pełnił także funkcję redaktora niezależnego pisma „Zapis”, uczestniczył w protestach społecznych. Stan wojenny zastał go przy współpracy z pismami podziemnymi, po 1989 r. powołał do istnienia Stowarzyszenie Pisarzy Polskich, w którym peł-

\footnotetext{
9 Por. Wintymnym oświetleniu.
} 
nił w latach 1990-1996 funkcję wiceprezesa, był przewodniczącym jury Nagrody im. Józefa Mackiewicza.

Istotną rolę w kształtowaniu dyskursu historycznoliterackiego w dwudziestym wieku odegrały także media. Tomasz Burek był gościem i współpracownikiem wielu rozgłośni m.in. występował w Radio Wolna Europa, w Programie II Polskiego Radia, w Radio Bis. Prowadzone przez niego (przy współpracy z Piotrem Matywieckim i Iwoną Smolką) audycje w Programie II Polskiego Radia na zawsze pozostaną w pamięci słuchaczy. Niezwykła kultura słowa, trzeźwy osąd wydarzeń kulturalnych i społecznych, interesujące, historyczne konteksty przyciągały odbiorców audycji literackich, które nie miały wyłącznie popularyzatorskiego charakteru. O takim właśnie celu prelekcji literackich wspominał Burek już wcześniej, w rozprawie pt. Jaka historia literatury jest nam dziś potrzebna? Wzorem romantyków dostrzegał konieczność sięgania do źródeł słowa poetyckiego, podejmowania nieustannego wysiłku, by wypowiadać „prawdy ukryte”, „rzeczy ostateczne”. Adrian Gleń ocenił te zabiegi jako „doświadczanie zapasów między doczesnością a wiecznością [ ... ] uprawianych przez tych, za którymi warto podążać” (Gleń 2016: 8). Rola krytyka i historyka literatury byłaby zatem podobna do roli ucznia z Saïs, który wierzy, że odkryje swoje przeznaczenie.

\section{Bibliografia}

Bolecki, Włodzimierz 2016. „Burek był i jest buntownikiem”. Topos 5: 113-114.

Burek, Tomasz 1981. „Dialog wolności i konieczności albo historyczne wtajemniczenie”. Teksty: teoria literatury, krytyka, interpretacja 4-5 (58-59): 93-114.

- 2001a. Dzieło niczyje. Kraków: Wydawnictwo Literackie.

- 2001b. Dziennik kwarantanny. Kraków: Wydawnictwo Acana.

Dakowicz, Przemysław 2016. „Płaszcz Putramenta i koniec świata. Z Tomaszem Burkiem rozmawia Przemysław Dakowicz". Topos 5: 21-52.

Gleń, Adrian 2016. „Tłumacz wspólnoty. Laudacja dla Tomasza Burka”. Topos 6: 7-8.

Libera, Antoni 2016. „Laudacja z okazji przyznania Tomaszowi Burkowi Medalu Gloria Artis w Ministerstwie Kultury w Warszawie 7 marca 2016 roku”. Topos 5: 53-55.

Novalis 1983. Aforyzmy. Warszawa: Państwowy Instytut Wydawniczy

- 1984. Uczniowie z Saïs. Warszawa: Czytelnik. 